\title{
Nickelphosphide from the Vicenice octahedrite: Rietveld crystal structure refinement of a synthetic analogue
}

\author{
R. SKÁlA* AND M. DRÁBEK \\ Czech Geological Survey, Klárov 3/131, CZ-11821 Praha 1, Czech Republic
}

\section{ABSTRACT}

The original description of nickelphosphide from the Butler meteorite $\left[\left(\mathrm{Ni}_{1.83} \mathrm{Fe}_{1.21}\right)_{\Sigma 3.04} \mathrm{P}_{0.96}\right.$ to $\left.\left(\mathrm{Ni}_{1.71} \mathrm{Fe}_{1.28} \mathrm{Co}_{0.01}\right)_{\Sigma 3.00} \mathrm{P}_{1.00}\right]$ lacks detailed and accurate powder data - with only 11 observed reflections down to $1.37 \mathrm{~A}$. Consequently, no crystal structure information for this phase is available. Here we present the crystal structure for a synthetic analogue of the phase found in the Vicenice IID medium octahedrite (with a mean empirical formula of $\left.\left(\mathrm{Ni}_{1.69} \mathrm{Fe}_{1.31}\right)_{\Sigma 3.00} \mathrm{P}_{1.00}\right)$ and a hypothetical $\mathrm{Ni}_{3} \mathrm{P}$ end-member. Unit-cell dimensions of the synthetic analogue of $\mathrm{Ni}_{1.68} \mathrm{Fe}_{1.33} \mathrm{P}_{0.99}$ composition from individual peak profile fitting of XRD data collected with $\mathrm{Cu}$ radiation are $a=9.0168(2) \AA, c=$ 4.4491(1) $\mathrm{A}, V=361.72(1) \AA^{3}$ and those for $\mathrm{Ni}_{3} \mathrm{P}$ composition are $a=8.9546(1) \AA, c=4.38714(8) \AA$, $V=351.783(8) \AA^{3}$. The space group of the mineral is $I \overline{4}$ and $Z=8$. The crystal structure refined from powder data by the Rietveld method is consistent with that refined and published for $\mathrm{Fe}_{3} \mathrm{P}$ and $\mathrm{Ni}_{3} \mathrm{P}$ synthetic compounds as well as Fe-dominant schreibersite from single-crystal data. However, because of the similarity of the scattering of iron and nickel, we were not able to refine directly the site occupancies in the synthetic analogue of the nickelphosphide from the Vicenice iron meteorite.

KEYwORDs: nickelphosphide, Vicenice, Rietveld refinement, crystal structure, iron meteorites.

\section{Introduction}

BRITVIN et al. (1999) described nickelphosphide as a new mineral from the ungrouped plessitic Butler octahedrite and discovered it also in the ungrouped Ni-rich ataxite Onello (Kopylova et al., 1999). Britvin et al. (1999) also reported literature analyses from several other meteorites indicating that nickelphosphide occurrences are not restricted to only two meteoritic irons. In the Onello ataxite, nickelphoshide is accompanied by another phosphide - allabogdanite $(\mathrm{Fe}, \mathrm{Ni})_{2} \mathrm{P}$ (Britvin et al., 2002).

Skála and Frýda (1999), independently of the observations of Britvin et al. described the phase corresponding to a Ni-dominant member of the $\mathrm{Fe}_{3} \mathrm{P}-\mathrm{Ni}_{3} \mathrm{P}$ solid solution from the Vicenice IID medium octahedrite. However, they were not able to characterize the phase in more detail due to its

*E-mail: skala@cgu.cz

DOI: $10.1180 / 0026461036740134$ small grain size. The composition of this particular material was used as a starting chemistry for preparation of synthetic analogues.

The goal of the present paper was to provide the crystal structure data for this mineral.

\section{Experimental}

We synthesized both analogues to the nickelphosphide encountered in the Vicenice octahedrite and hypothetic end-member of the schreibersitenickelphosphide solid solution of $\mathrm{Ni}_{3} \mathrm{P}$ composition. Synthetic materials were prepared in evacuated, sealed silica tubes in which carefully weighed amounts of the starting chemicals were heated. Samples were repeatedly ground under acetone and reheated at the given temperature until equilibrium was attained. Details of the sample syntheses and sample labelling are given in Table 1. Starting substances were nickel powder of $99.999 \%$ purity (SPEX Industries, Inc., USA), Fe sponge of $99.999 \%$ purity (Johnson Matthey Chemicals Limited, England) 


\section{R. SKÁLA AND M. DRÁBEK}

TABLE 1. Conditions for sample syntheses.

\begin{tabular}{lllll}
\hline Sample & $\mathrm{P}-33$ & $\mathrm{P}-33 / 3$ & \multicolumn{1}{c}{$\mathrm{P}-43$} & \multicolumn{1}{c}{$\mathrm{P}-44$} \\
\hline Starting composition & $\mathrm{Ni}_{3} \mathrm{P}$ & $\mathrm{Ni}_{3} \mathrm{P}$ & $\mathrm{Ni}_{1.69} \mathrm{Fe}_{1.31} \mathrm{P}$ & $\mathrm{Ni}_{1.69} \mathrm{Fe}_{1.31} \mathrm{P}$ \\
$T\left({ }^{\circ} \mathrm{C}\right)$ & 535 & 600 & 600 & 820 \\
$t(\mathrm{~h})$ & 595 & 2635 & 2635 & 212 \\
& & & & \\
\hline
\end{tabular}

and red phosphorus powder of $99 \%$ purity (Aldrich, Germany). Before being used for syntheses, $\mathrm{Fe}$ and $\mathrm{Ni}$ were heated for $4 \mathrm{~h}$ in a stream of $\mathrm{H}_{2}$ at $700^{\circ} \mathrm{C}$. Phosphorus powder was washed in distilled water and acetone and then dried under vacuum. Samples were heated in horizontal tube furnaces in which the temperatures were controlled electronically. The maximum temperature variation did not exceed $\pm 2^{\circ} \mathrm{C}$. After each run, the silica tubes with synthesized charges were quenched in ice-water.

The chemical composition of the synthetic analogues was characterized in polished sections by an energy-dispersive system Oxford Link ISIS 300 (with an ultra-thin detector window) connected to a CamScan IV scanning electron microscope. Accelerating voltage was set to $20 \mathrm{kV}$ and sample current to $2.5 \mathrm{nA}$. Spectrum acquisition time was $40 \mathrm{~s}$. Beam current was measured with a Faraday cup. Synthesized phases were analysed for $\mathrm{Fe}, \mathrm{Ni}$ and $\mathrm{P}$ only and the standards used were pure $\mathrm{Fe}$ and $\mathrm{Ni}$ and synthetic $\mathrm{Ni}_{3} \mathrm{P}$. Details on chemical data acquisition for nickelphosphide in the Vicenice octahedrite are given in Skála et al. (2000).

Powder data for synthetic phosphides were collected independently on two diffractometers in two distinct diffraction geometries. Data for all synthetic samples were acquired on a Philips X'Pert MPD diffractometer in reflecting geometry (two powder patterns per each individual composition, patterns are labelled with 'a' or ' $b$ ' following sample description, see Table 2) and data for the samples P-33 and P-44 were also collected on a STADI P STOE diffractometer in transmission geometry. The powder data in reflecting geometry are acquired with $\mathrm{Cu}-\mathrm{K} \alpha_{1,2}$ radiation and those in reflecting geometry were collected using Co- $K \alpha_{1}$ radiation. Details of the powder data collection conditions are given in Table 2. Samples were placed atop low-background silicon sample holders in the case of reflecting arrangement and in between mylar foils in transmission geometry.

\section{Chemical composition}

Empirical formulae of the synthesized phases were recalculated from analyses assuming a total of four elements per formula unit. The chemical composition is summarized in Table 3. The synthetic analogues are very close to the composition of the natural phase - the difference in their chemistry and the corresponding natural

TABLE 2. Conditions for the powder data acquisition.

\begin{tabular}{|c|c|c|c|c|c|c|c|c|}
\hline \multirow{2}{*}{$\frac{\text { Sample }}{\text { Pattern }}$} & \multirow{2}{*}{$\begin{array}{l}\mathrm{P}-33 \\
\mathrm{P}-33\end{array}$} & \multirow{2}{*}{$\begin{array}{l}\mathrm{P}-33 / 3 \\
\mathrm{P}-33 / 3\end{array}$} & \multicolumn{2}{|c|}{ P-43 } & \multicolumn{2}{|c|}{ P-44 } & \multirow{2}{*}{$\begin{array}{l}\mathrm{P}-33 / 3 \\
\mathrm{P}-33 / 3 \mathrm{~S}\end{array}$} & \multirow{2}{*}{$\frac{\mathrm{P}-44}{\mathrm{P}-44 \mathrm{~S}}$} \\
\hline & & & $\mathrm{P}-43 / \mathrm{a}$ & $\mathrm{P}-43 / \mathrm{b}$ & $\mathrm{P}-44 / \mathrm{a}$ & $\mathrm{P}-44 / \mathrm{b}$ & & \\
\hline Geometry & \multirow{2}{*}{\multicolumn{6}{|c|}{ Reflecting }} & \multicolumn{2}{|c|}{ Transmission } \\
\hline Monochromator & & & & $y$, graphite & & & \multirow{2}{*}{\multicolumn{2}{|c|}{$\begin{array}{c}\text { Primary, germanium } \\
\text { Co- } K \alpha_{1}\end{array}$}} \\
\hline Radiation & \multicolumn{6}{|c|}{$\begin{array}{c}\mathrm{Cu}-K \alpha_{1,2} \\
\text { Cecondary, grapnite }\end{array}$} & & \\
\hline Angular range & & & & & & & & \\
\hline Start angle $\left({ }^{\circ} 2 \theta\right)$ & 10.00 & 9.99 & 10.00 & 21.000 & 10.00 & 10.00 & 22.98 & 22.98 \\
\hline Step size $\left({ }^{\circ} 2 \theta\right)$ & 0.02 & 0.02 & 0.02 & 0.015 & 0.02 & 0.02 & 0.01 & 0.01 \\
\hline End angle $\left({ }^{\circ} 2 \theta\right)$ & 150.00 & 150.01 & 150.00 & 148.995 & 150.00 & 150.00 & 100.15 & 100.15 \\
\hline Count time per step (s) & 8.0 & 8.0 & 9.0 & 26.6 & 8.0 & 9.0 & 5.0 & 5.0 \\
\hline
\end{tabular}


TABle 3. Comparison of the chemical composition of nickelphosphide from the Vicenice iron meteorite and its synthetic analogues.

\begin{tabular}{|c|c|c|c|c|c|c|}
\hline & \multicolumn{2}{|c|}{ Vicenice } & \multicolumn{2}{|c|}{ P-43 } & \multicolumn{2}{|c|}{ P-44 } \\
\hline \multicolumn{7}{|c|}{ Mean and esd of analytical data in wt.\% (value and corresponding esd) } \\
\hline $\mathrm{Ni}$ & 48.6 & 0.7 & 48.4 & 0.4 & 48.6 & 0.4 \\
\hline $\mathrm{Fe}$ & 35.9 & 0.7 & 36.0 & 0.4 & 36.6 & 0.3 \\
\hline Co & 0.12 & 0.07 & & & & \\
\hline $\mathrm{Cr}$ & 0.03 & 0.02 & & & & \\
\hline $\mathrm{P}$ & 15.1 & 0.2 & 15.4 & 0.2 & 15.2 & 0.1 \\
\hline S & 0.04 & 0.03 & & & & \\
\hline Total & 99.8 & 0.6 & 99.8 & 0.6 & 100.4 & 0.7 \\
\hline \multicolumn{7}{|c|}{ Range of analytical data in wt.\% (minimum and maximum) } \\
\hline $\mathrm{Ni}$ & 46.5 & 50.2 & 47.8 & 49.4 & 47.9 & 49.3 \\
\hline $\mathrm{Fe}$ & 34.8 & 38.0 & 35.4 & 36.6 & 36.0 & 37.2 \\
\hline Co & 0.00 & 0.27 & & & & \\
\hline $\mathrm{Cr}$ & 0.01 & 0.09 & & & & \\
\hline $\mathrm{P}$ & 14.8 & 15.5 & 15.2 & 15.8 & 14.8 & 15.5 \\
\hline $\mathrm{S}$ & 0.01 & 0.13 & & & & \\
\hline Total & 98.3 & 101.9 & 98.7 & 101.1 & 99.4 & 101.5 \\
\hline \multicolumn{7}{|c|}{ Mean and esd of empirical formulae in a.p.f.u. units (value and corresponding esd) } \\
\hline $\mathrm{Ni}$ & 1.69 & 0.02 & 1.678 & 0.011 & 1.678 & 0.010 \\
\hline $\mathrm{Fe}$ & 1.31 & 0.02 & 1.313 & 0.009 & 1.328 & 0.008 \\
\hline Co & 0.003 & 0.003 & & & & \\
\hline $\mathrm{Cr}$ & 0.001 & 0.001 & & & & \\
\hline $\mathrm{P}$ & 0.995 & 0.008 & 1.009 & 0.009 & 0.994 & 0.007 \\
\hline S & 0.002 & 0.002 & & & & \\
\hline \multicolumn{7}{|c|}{ End member contents in mol.\% (minimum, maximum, mean and esd) } \\
\hline $\mathrm{Ni}_{3} \mathrm{P}$ - range & 53.9 & 57.4 & 55.6 & 56.7 & 55.2 & 56.4 \\
\hline $\mathrm{Ni}_{3} \mathrm{P}-$ mean & 56.2 & 0.8 & 56.1 & 0.3 & 55.8 & 0.3 \\
\hline $\mathrm{Fe}_{3} \mathrm{P}-$ range & 42.6 & 46.1 & 43.3 & 44.4 & 43.6 & 44.8 \\
\hline $\mathrm{Fe}_{3} \mathrm{P}-$ mean & 43.7 & 0.8 & 43.9 & 0.3 & 44.2 & 0.3 \\
\hline
\end{tabular}

material is $<0.6$ rel.\% of individual elemental contents - see Fig. 1.

\section{Crystal structure data}

Nickelphosphide occurring in the Vicenice octahedrite could not be effectively removed from meteorite slabs due to its small dimensions. Attempts to synthesize single crystals of the chemical composition corresponding to that found in the natural phase from the meteorite failed. Therefore, we decided to collect and evaluate diffraction data on powdered synthetic analogues characterized chemically in detail in the previous section.

The step-scanned powder diffraction data were processed by the program XFIT (Coelho and
Cheary, 1997) applying split asymmetric Pearson VII profile-shape-function to yield angular peak positions and peak integral intensities. In the original paper on nickelphosphide definition, Britvin et al. (1999) gave only 11 lines down to $1.379 \AA$; our data exhibit 28-30 lines down to this limit. In total, we resolved up to 101 lines and indexed them with 116 diffraction indices down to $0.803 \AA$ in the pattern $P 43 / b$ (Skála and Drábek, 2002).

The unit-cell dimensions were calculated from individual fitted peak positions in a spreadsheet calculator using the relation $1 / d^{2}=\left(h^{2}+k^{2}\right) a^{* 2}+$ $l^{2} c^{*^{2}}+\mathrm{CT}$, where $d$ is $d$ spacing, $h, k, l$ diffraction indices, $a^{*}$ and $c^{*}$ reciprocal unit-cell dimensions, and CT the refinable correction factor corresponding to a peak shift due to a sample 

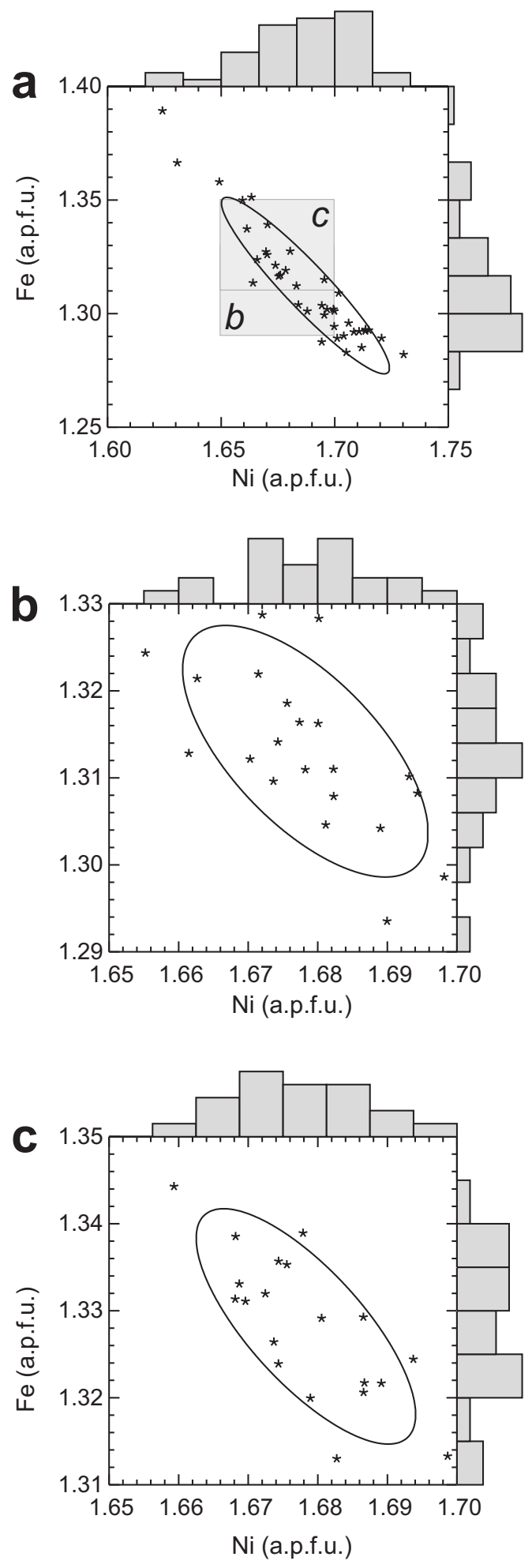

displacement (of $\cos \theta$ form for reflecting geometry and $\sin 2 \theta$ form for transmission geometry, respectively) and/or zero-shift. Lengths of unit-cell edges are compared in Table 4. Based on the comparison to an external $\mathrm{LaB}_{6}$ standard, the accuracy of the refined unitcell dimensions is better than 0.005 rel.\%. The difference in unit-cell dimensions is primarily due to the narrower angular range covered by the data acquired with Co radiation in transmission geometry - in the reflecting arrangement we observed peaks down to $0.8 \AA$ whereas in the transmission geometry we attained peaks down to $1.2 \AA$ only.

Rietveld refinements were carried out on the data collected in the transmission geometry with strictly monochromatic radiation. The data acquired in the reflecting geometry using a graphite secondary monochromator unfortunately did not provide reliable enough intensity information, and extensive peak overlaps due to $\alpha 1 \alpha 2$ doublets complicated refining better structural data. Agreement factors were considerably higher for these refinements compared to those yielded from the data collected in the transmission arrangement with monochromatic radiation. Also, standard uncertainties of the refined parameters from the powder data from reflecting geometry were about an order of magnitude higher than those from the data acquired in the transmission arrangement.

The Rietveld refinement of the crystal structures for hypothetic end-member and synthetic analogue of nickelphosphide from the Vicenice octahedrite were performed using the program FullProf.2k (Rodríguez-Carvajal, 1990, 2001) with the graphical shell of the WinPlotr program (Roisnel and Rodríguez-Carvajal, 2001). The starting models of the structure were derived from published single-crystal data for $\mathrm{Ni}_{3} \mathrm{P}$ (Aronsson, 1955; Rundquist et al., 1962), $\mathrm{Fe}_{3} \mathrm{P}$ (Rundquist, 1962), and meteoritic schreibersite (Doenitz, 1968 and 1970) - i.e. the crystal structure is tetragonal with space group $I \overline{4}$ (No. 82) with four $8 g$ sites of which three are

Fig. 1. Chemical composition of nickelphosphide as Ni and Fe contents (a.p.f.u.). Data for natural nickelphosphide from the Vicenice octahedrite $(a)$ are compared to its two synthetic counterparts P-43 (b) and P-44 (c). ELL confidence ellipses are drawn for 0.6827 probability. Shadowed boxes in plot $(a)$ indicate the range of plots $(b)$ and $(c)$, respectively, in the axis system of plot $(a)$. 
TABLE 4. Unit-cell dimensions of synthetic nickelphosphides. The data come from individual peak profile fitting.

\begin{tabular}{|c|c|c|c|c|c|c|c|c|}
\hline \multirow{3}{*}{$\begin{array}{l}\text { Sample } \\
\text { Pattern } \\
\text { Composition }\end{array}$} & \multirow{3}{*}{$\begin{array}{l}\mathrm{P}-33 \\
\mathrm{P}-33 \\
\mathrm{Ni}_{3} \mathrm{P}\end{array}$} & \multicolumn{2}{|c|}{ P-33/3 } & \multicolumn{2}{|c|}{ P43 } & \multicolumn{3}{|c|}{ P-44 } \\
\hline & & $\mathrm{P}-33 / 3$ & $\mathrm{P}-33 / 3 \mathrm{~S}$ & $\mathrm{P}-43 / \mathrm{a}$ & $\mathrm{P}-43 / \mathrm{b}$ & P-44/a & $\mathrm{P}-44 / \mathrm{b}$ & P-44S \\
\hline & & \multicolumn{2}{|c|}{$\mathrm{Ni}_{3} \mathrm{P}$} & \multicolumn{2}{|c|}{$\mathrm{Ni}_{1.68} \mathrm{Fe}_{1.313} \mathrm{P}_{1.009}$} & \multicolumn{3}{|c|}{$\mathrm{Ni}_{1.68} \mathrm{Fe}_{1.328} \mathrm{P}_{0.994}$} \\
\hline$a(\AA)$ & $8.9546(1)$ & $8.9542(1)$ & $8.9548(9)$ & $9.0158(2)$ & ) $9.0161(1)$ & $9.0168(2)$ & $9.0168(2)$ & $9.016(1)$ \\
\hline$c(\AA)$ & $4.38714(8)$ & $4.38699(9)$ & $4.3869(5)$ & $4.4494(1)$ & $4.4497(1)$ & $4.4491(1)$ & $4.4492(2)$ & $4.4483(6)$ \\
\hline$V\left(\AA^{3}\right)$ & $351.783(8)$ & $351.748(9)$ & $351.78(7)$ & $361.67(2)$ & $361.72(1)$ & $361.72(1)$ & $361.74(1)$ & $361.57(9)$ \\
\hline$N_{\operatorname{lin}}$ & 99 & 99 & 43 & 100 & 101 & 88 & 86 & 39 \\
\hline$M_{\text {lin }}$ & 30 & 30 & 28 & 27 & 28 & 29 & 26 & 26 \\
\hline$N_{\text {ref }}$ & 119 & 119 & 45 & 117 & 118 & 105 & 100 & 42 \\
\hline$M_{\text {ref }}$ & 118 & 118 & 45 & 117 & 116 & 105 & 100 & 42 \\
\hline
\end{tabular}

$N_{\text {lin }}=$ total number of resolved peaks; $M_{\text {lin }}=$ number of resolved peaks down to reflection 213 (Britvin et al. (1999) found 11 peaks down to this line); $N_{\text {ref }}=$ total number of diffraction indices assigned to resolved peaks; $M_{\text {ref }}=$ number of diffraction indices used for unit-cell dimensions refinements.

Britvin et al. (1999) gave the unit-cell dimensions of the nickelphosphide of the $2^{\text {nd }}$ type from the Butler iron meteorite of $\left(\mathrm{Ni}_{1.71} \mathrm{Fe}_{1.28} \mathrm{Co}_{0.01}\right) \mathrm{P}_{1.00}$ composition as $a=8.99 \AA, c=4.396 \AA$ and $V=355 \AA^{3}$. If the minimization procedure used in present paper is applied to the original data, the unit-cell edges become $a=9.03(4) \AA, c=$ $4.39(1) \AA$ and $V=358(3) \AA^{3}$ which is in better agreement with the values observed by us.

Based on the comparison to an external $\mathrm{LaB}_{6}$ standard, the accuracy of the refined unit-cell dimensions is better than 0.005 rel.\%.

occupied by metallic atoms and one by phosphorus. The profile-shape function used to approximate peaks in the powder pattern was of pseudo-Voigt type. The background was read from a file. Sample displacement was corrected by a sine correction term. The refined parameters included those describing peak shape and width, fixed background linear transformation coefficient, peak asymmetry, unit-cell dimensions, sine sample displacement correction term, fractional coordinates and isotropic temperature factors. In total, we refined 29 parameters. The convergence criterion, $\varepsilon$, forcing the termination of the refinement when parameters shifts $<\varepsilon \times \sigma$, was set to 0.1 .

The synthetic analogue of nickelphosphide from the Vicenice iron meteorite contains both $\mathrm{Ni}$ and $\mathrm{Fe}$ in its structure. From the single-crystal refinements for natural schreibersites (e.g. Doenitz, 1968, 1970; Skála and Císařová, 1999, 2000, 2001) and magnetic refinement from neutron data for isostructural $\left(\mathrm{Fe}_{1-x} \mathrm{Co}_{x}\right)_{3} \mathrm{P}$ (Liu et al., 1998) it is known that there is uneven distribution of metallic atoms over three crystallographically non-equivalent sites within the structure. We also attempted to refine site distribution for both types of atoms within the structure; however, the scattering factors are so close that they could not be resolved effectively from the data available. Therefore, we adopted the procedure used originally by Doenitz (1970) for his refinement of the crystal structure of schreibersite (variety rhabdite) crystal from the North Chile (Tocopilla) iron meteorite from Weissenberg data. We modelled several possible site occupancies, and based on the final Bragg agreement factor we selected the model with the best overall fit. The results of the Rietveld crystal structure refinement are summarized in Table 5 and the calculated selected bond distances are listed in Table 6. Difference Fourier maps were calculated by a Fourier program with a graphical shell of Gfour (Gonzáles-Platas and RodríguezCarvajal, 1999). No structurally meaningful residuals were found in the difference Fourier maps and maximum differences were not greater than $\pm 0.5 \mathrm{e}^{-}$(Table 5). Nickelphosphide is without doubt of $\mathrm{Fe}_{3} \mathrm{P}$ structure type. The final Rietveld plots are shown in Fig. 2.

The crystal structure of nickelphosphide when viewed down to [100] consists of alternating layers built up from $\mathrm{Me} 1$ and $\mathrm{Me} 3$ atoms, located at approximately $1 / 4$ and $3 / 4$ of the unit-cell height, and $M 2$ and $\mathrm{P}$, located at about 0 and $1 / 2$ of the unit-cell height, respectively (see Fig. $3 a$ ). The view down to [001], shown in Fig. 3b, indicates tetragonal symmetry and also reveals coordination environments of individual sites of the 
R. SKÁLA AND M. DRÁBEK

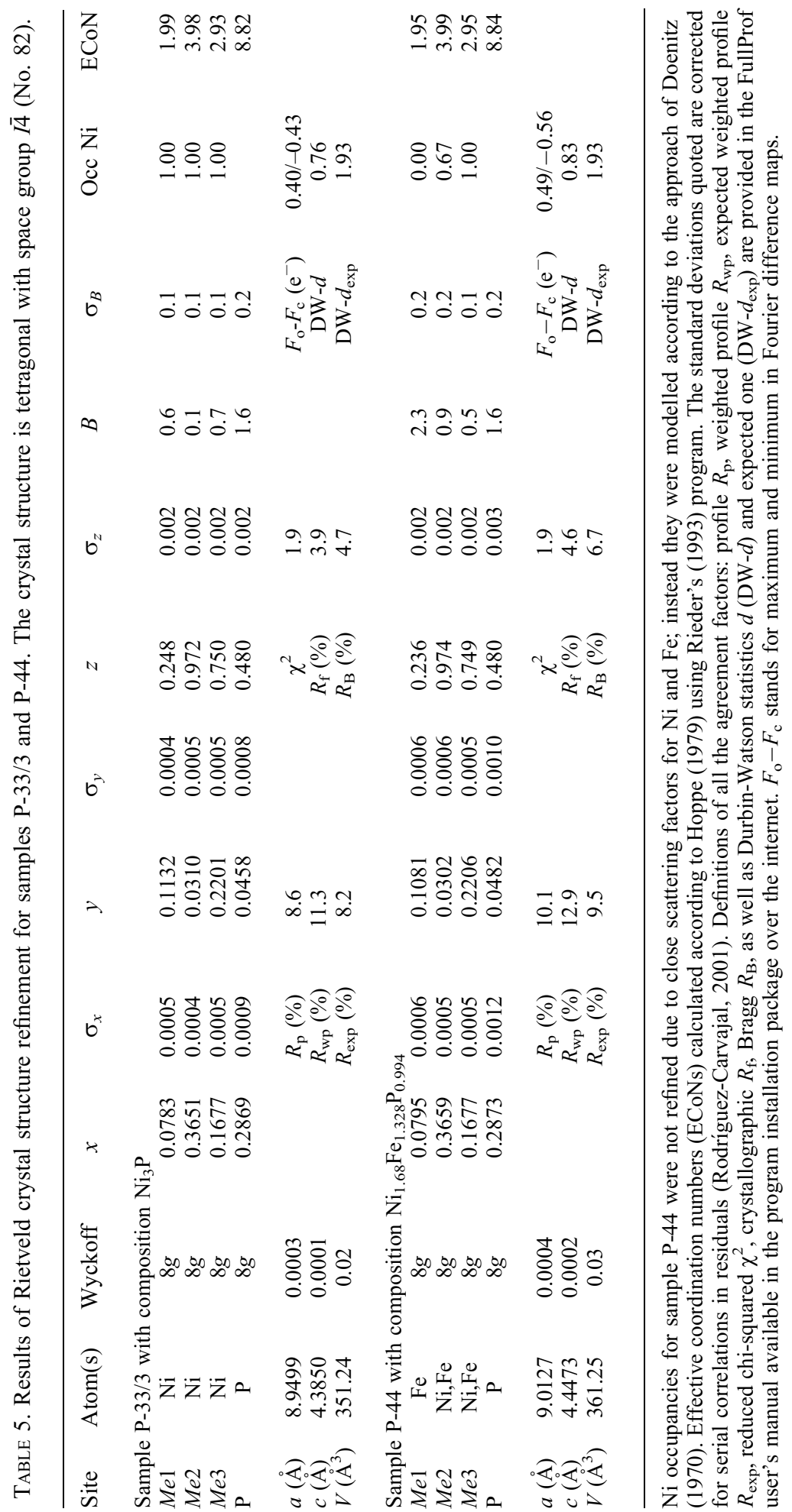


TABLE 6. Selected bond distances and angles.

\begin{tabular}{|c|c|c|c|c|c|c|c|c|}
\hline \multirow{2}{*}{ Atom \#1 } & \multirow{2}{*}{ Atom $\# 2$} & \multicolumn{2}{|c|}{ Distances $(\AA)$} & \multirow{2}{*}{ Atom \#1 } & \multirow{2}{*}{ Atom \#2 } & \multirow{2}{*}{ Atom \#3 } & \multicolumn{2}{|c|}{ Angles $\left({ }^{\circ}\right)$} \\
\hline & & P-33/3 & P-44 & & & & $\mathrm{P}-33 / 3$ & P-44 \\
\hline$M e 1$ & $\mathrm{P}$ & $2.210(5)$ & $2.231(6)$ & $M e 1$ & $\mathrm{P}$ & $M e 1$ & $78.25(2)$ & $78.62(3)$ \\
\hline$M e 1$ & $\mathrm{P}$ & $2.253(5)$ & $2.351(6)$ & $M e 1$ & $\mathrm{P}$ & $M e 2$ & $71.37(2)$ & $70.50(2)$ \\
\hline$M e 1$ & $M e 1$ & $2.464(3)$ & $2.419(3)$ & $M e 1$ & $\mathrm{P}$ & $M e 2$ & $80.16(2)$ & $78.76(3)$ \\
\hline$M e 1$ & $M e 2$ & $2.639(3)$ & $2.691(4)$ & $M e 1$ & $\mathrm{P}$ & $M e 2$ & $95.33(2)$ & $95.29(2)$ \\
\hline$M e 1$ & $M e 3$ & $2.514(5)$ & $2.520(6)$ & $M e 1$ & $\mathrm{P}$ & $\mathrm{Me} 3$ & $69.49(2)$ & $71.80(3)$ \\
\hline$M e 1$ & $M e 3$ & $2.530(5)$ & $2.620(6)$ & $M e 1$ & $\mathrm{P}$ & $M e 3$ & $72.92(2)$ & $73.67(2)$ \\
\hline$M e 2$ & $\mathrm{P}$ & $2.270(5)$ & $2.312(7)$ & $M e 1$ & $\mathrm{P}$ & $M e 3$ & $78.50(2)$ & $76.56(2)$ \\
\hline$M e 2$ & $\mathrm{P}$ & $2.306(4)$ & $2.331(5)$ & $M e 1$ & $\mathrm{P}$ & $M e 3$ & $68.54(2)$ & $68.95(3)$ \\
\hline$M e 2$ & $\mathrm{P}$ & $2.336(4)$ & $2.335(5)$ & $M e 1$ & $\mathrm{P}$ & $M e 3$ & $74.56(2)$ & $73.85(2)$ \\
\hline$M e 2$ & $\mathrm{P}$ & $2.340(5)$ & $2.367(7)$ & $M e 2$ & $\mathrm{P}$ & $M e 2$ & $64.52(2)$ & $64.17(2)$ \\
\hline$M e 2$ & $M e 2$ & $2.478(2)$ & $2.478(3)$ & $M e 2$ & $\mathrm{P}$ & $M e 2$ & $69.21(2)$ & $69.56(2)$ \\
\hline$M e 2$ & $M e 2$ & $2.617(4)$ & $2.651(5)$ & $M e 2$ & $\mathrm{P}$ & $M e 2$ & $69.74(2)$ & $69.63(2)$ \\
\hline$M e 2$ & $M e 3$ & $2.518(3)$ & $2.532(4)$ & $M e 2$ & $\mathrm{P}$ & $M e 2$ & $79.98(2)$ & $79.90(3)$ \\
\hline$M e 2$ & $M e 3$ & $2.556(3)$ & $2.577(4)$ & $M e 2$ & $\mathrm{P}$ & $M e 2$ & $80.59(2)$ & $79.98(3)$ \\
\hline$M e 2$ & $M e 3$ & 2.633(3) & $2.671(4)$ & $M e 2$ & $\mathrm{P}$ & $M e 3$ & $64.83(2)$ & $65.38(2)$ \\
\hline$M e 3$ & $\mathrm{P}$ & $2.229(5)$ & $2.238(6)$ & $M e 2$ & $\mathrm{P}$ & $M e 3$ & $65.88(2)$ & $66.05(2)$ \\
\hline$M e 3$ & $\mathrm{P}$ & $2.241(5)$ & $2.278(5)$ & $M e 2$ & $\mathrm{P}$ & $M e 3$ & $66.63(2)$ & $66.10(2)$ \\
\hline$M e 3$ & $\mathrm{P}$ & $2.361(4)$ & $2.358(5)$ & $M e 2$ & $P$ & $M e 3$ & $68.39(2)$ & $67.91(2)$ \\
\hline$M e 3$ & $\mathrm{Me} 3$ & $2.695(4)$ & $2.725(5)$ & $M e 2$ & $\mathrm{P}$ & $M e 3$ & $71.61(2)$ & $71.87(2)$ \\
\hline & & & & $M e 3$ & $\mathrm{P}$ & $M e 3$ & $71.84(2)$ & $72.68(2)$ \\
\hline
\end{tabular}

structure. Phosphorus is nine-fold coordinated by $2 \mathrm{Me} 1$ atoms, $4 \mathrm{Me} 2$ atoms and $3 \mathrm{Me} 3$ atoms. The coordination numbers of $\mathrm{Me} 1, M e 2$ and $M e 3$ sites are consistent with their calculated effective values (ECoNs; Hoppe, 1979; Rieder, 1993) listed in Table 5.

\section{Conclusions}

Analysing powder data of the synthetic analogue of nickelphosphide from the Vicenice iron meteorite, we were able to resolve a total of 101 lines in the powder pattern down to $0.803 \AA$ compared to 11 lines down to $1.379 \AA$ in the original description of this mineral by Britvin et al. (1999). The completeness of the powder data allowed us to refine a reliable set of unit-cell dimensions which fits the trend observed for the complete $\mathrm{Fe}_{3} \mathrm{P}-\mathrm{Ni}_{3} \mathrm{P}$ solid solution (Skála and Drábek, 2000). The unit-cell parameters we obtained are, when the same minimization procedure is applied for the refinement, in relatively good agreement with those refined from the powder data given for nickelphosphide from the Butler meteorite by Britvin et al. (1999).

Rietveld crystal structure refinement of the powder data revealed that the crystal structure of the synthetic nickelphosphide analogue is of the same type as the structure of the hypothetical endmembers of the shreibersite-nickelphosphide solid solution $-\mathrm{Fe}_{3} \mathrm{P}$ (Rundquist, 1962) and $\mathrm{Ni}_{3} \mathrm{P}$ (Aronsson, 1955; Rundquist et al., 1962). Comparing several models with different siteoccupancies of $\mathrm{Fe}$ and $\mathrm{Ni}$ in crystallographically non-equivalent sites within the structure of nickelphosphide, it appears that individual sites prefer certain atoms as already noted in some previous single-crystal structure refinements for meteoritic schreibersites by, e.g. Doenitz (1970) and Skála and Císarová (1999, 2000, 2001).

\section{Acknowledgements}

This research was supported by the Grant Agency of the Czech Republic (grant no. 205/98/0655). The slice of the Vicenice octahedrite was kindly provided by Marcela Bukovanská, a curator of the meteorite collection of the National Museum in Prague. The authors are also indebted to Václav Vávra of the Department of Mineralogy of Masaryk University in Brno who collected the powder data on the STOE diffractometer. 

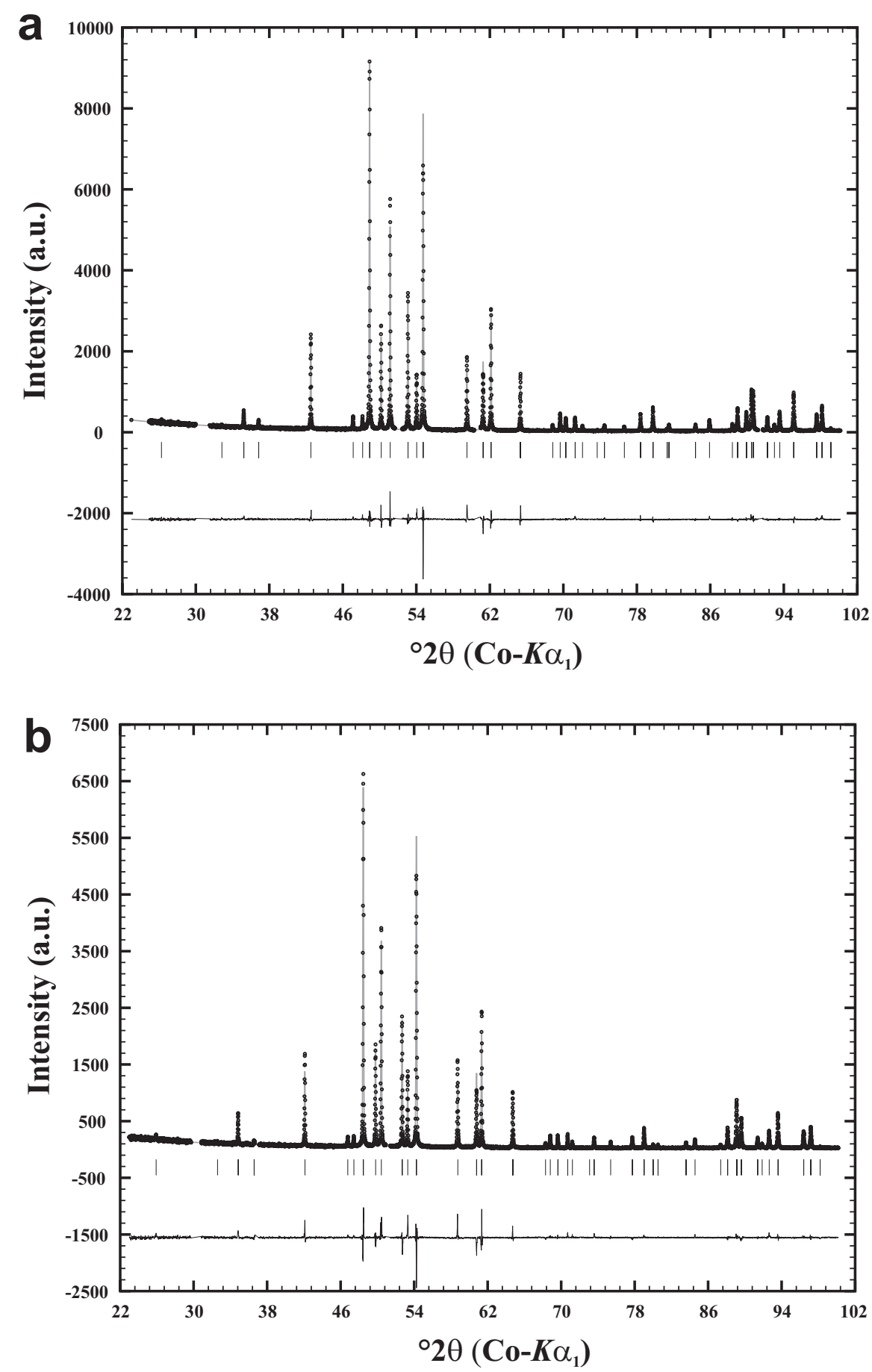

FIG. 2. Results of Rietveld crystal structure refinement. Observed, calculated and difference plots are shown for patterns P-33/S $(a)$ and P-44/S $(b)$. Peak positions are indicated by vertical tick marks. 

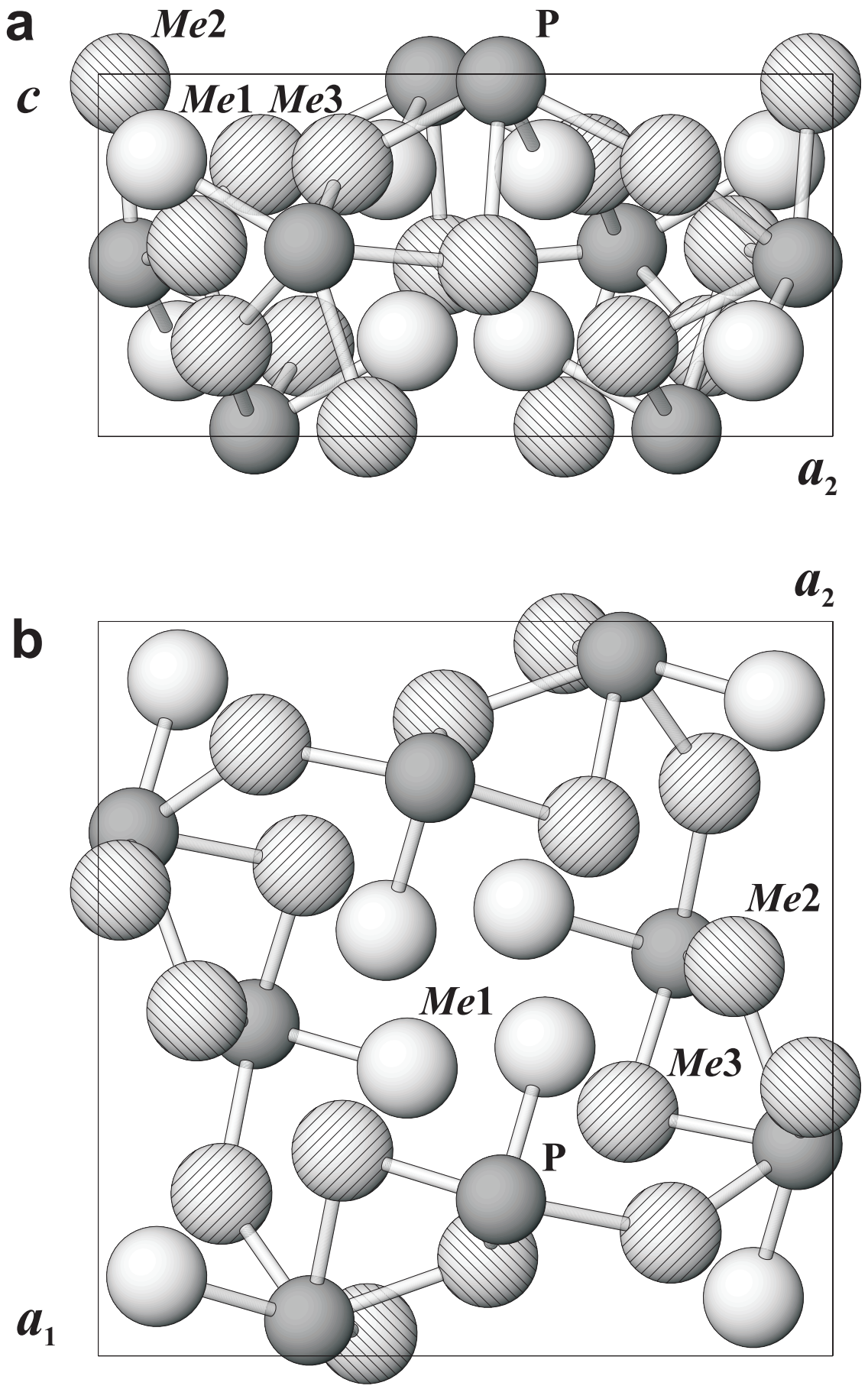

FIG. 3. Projections of the crystal structure of synthetic nickelphosphide analogue $(a)$ with a view down [100] and $(b)$ down to [001]. Part $(a)$ shows layering in the structure whereas $(b)$ shows the tetragonal symmetry and coordination environments around individual sites of the structure. 


\section{R. SKÁLA AND M. DRÁBEK}

\section{References}

Aronsson, B. (1955) The crystal structure of $\mathrm{Ni}_{3} \mathrm{P}$. ( $\left.\mathrm{Fe}_{3} \mathrm{P}-\mathrm{Type}\right)$. Acta Chemica Scandinavica, 9, 137-140.

Britvin, S.N., Kolomensky, V.D., Boldyreva, M.M., Bogdanova, A.N., Kretser, Yu.L., Boldyreva, O.N. and Rudashevsky, N.S. (1999) Nickelphosphide $(\mathrm{Ni}, \mathrm{Fe})_{3} \mathrm{P}$ - the nickel analog of schreibersite. Zapiski Vserossijskogo Mineralogicheskogo Obschchestva, 128, 64-72.

Britvin, S.N., Rudashevsky, N.S., Krivovichev, S.V., Burns, P.C. and Polekhovsky, Yu.S. (2002) Allabogdanite, $(\mathrm{Fe}, \mathrm{Ni})_{2} \mathrm{P}$, a new mineral from the Onello meteorite: The occurrence and crystal structure. American Mineralogist, 87, 1245-1249.

Coelho, A.A. and Cheary, R.W. (1997) X-ray Line Profile Fitting Program, XFIT. School of Physical Sciences, University of Technology, Sydney, New South Wales, Australia. ftp://ftp.minerals.csiro.au/ $\mathrm{pub} / \mathrm{xtallography} /$ koalariet

Doenitz, F.D. (1968) Die Kristallstruktur des Meteoritenminerals Rhabdit. Naturwissenschaften, $\mathbf{5 5}, 387$.

Doenitz, F.D. (1970) Die Kristallstruktur des meteoritischen Rhabdits $(\mathrm{Fe}, \mathrm{Ni})_{3} \mathrm{P}$. Zeitschrift für Kristallographie, 131, 222-236.

González-Platas, J. and Rodríguez-Carvajal, J. (1999) Fourier \& GFourier Programs. Release: 01.12. Accion Integerada Hispano-Francesa HF1997-0188. Departamento de Física Fundamental II, Universidad de La Laguna, Tenerife, Spain.

Hoppe, R. (1979) Effective coordination numbers $(\mathrm{ECoN})$ and mean fictive ionic radii (MEFIR). Zeitschrift für Kristallographie, 150, 23-52.

Kopylova, A.G., Oleinikov, B.V., Sobolev, N.V. and Sushko O.A. (1999) The new iron meteorite Onello: A unique high-Ni ataxite. Transactions (Doklady) of the Russian Academy of Science, Earth Science Section, 368, 899-901.

Liu, H.-p., James, P., Broddefalk, A., Andersson, Y., Granberg, P. and Eriksson, O. (1998) Structural and magnetic properties of $\left(\mathrm{Fe}_{1-x} \mathrm{Co}_{x}\right)_{3} \mathrm{P}$ compounds: experiment and theory. Journal of Magnetism and Magnetic Materials, 189, 69-82.

Rieder, M. (1993) Program HOPPE for calculation of MEFIR, ECoN and mean (plus s.e.m.) from FIRs. Faculty of Science, Charles University, Prague, Czech Republic.

Rodríguez-Carvajal, J. (1990) FULLPROF: A program for Rietveld Refinement and Pattern Matching Analysis. Abstracts of the Satellite Meeting on
Powder Diffraction of the $\mathbf{X V}$ Congress of the IUCr. Toulouse, p. 127.

Rodríguez-Carvajal, J. (2001) FullProf.2k. Rietveld, Profile Matching \& Integrated Intensities Refinement of X-ray and/or Neutron Data (powder and/or single-crystal). Laboratoire Léon Brillouin, Centre d'Etudes de Saclay, Gif-sur-Yvette Cedex, France. ftp://charybde.saclay.cea.fr/pub/divers/fullp.

Roisnel, T. and Rodríguez-Carvajal, J. (2001) WinPLOTR. Laboratoire Léon Brillouin, Centre d'Etudes de Saclay, Gif-sur-Yvette Cedex, France. http://www-llb.cea.fr/fullweb/winplotr/winplotr.htm

Rundqvist, S. (1962) X-ray investigations of the ternary system Fe-B-P. Acta Chemica Scandinavica, 16, $1-19$.

Rundqvist, S., Hassler, E. and Lundvik, L. (1962) Refinement of the $\mathrm{Ni}_{3} \mathrm{P}$ structure. Acta Chemica Scandinavica, 16, 242-243.

Skála, R. and Císařová, I. (1999) Crystal structure of schreibersite from Toluca iron meteorite. Lunar and Planetary Science, XXX, Abstract \#1359, Lunar and Planetary Institute, Houston (CD-ROM).

Skála, R. and Císařová, I. (2000) Iron-nickel partitioning over nonequivalent sites in crystal structure of schreibersite from the Odessa iron meteorite. Meteoritics and Planetary Science, 35, supplement, A149-A150 (abstract).

Skála, R. and Císařová, I. (2001) Crystal structure of schreibersite from the meteoritic iron Sikhote Alin. Lunar and Planetary Science, XXXII, Abstract \#1564, Lunar and Planetary Institute, Houston (CD-ROM).

Skála, R. and Drábek, M. (2000) Variation of unit-cell dimensions of experimentally synthesized members

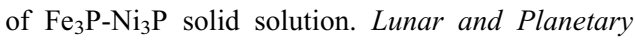
Science, XXXI, Abstract \#1564, Lunar and Planetary Institute, Houston (CD-ROM).

Skála, R. and Drábek, M. (2002) Powder data for synthetic analogue of a mineral nickelphosphide. Powder Diffraction, 17, 322-325.

Skála, R. and Frýda, J. (1999) Nickel-dominant schreibersite from Vicenice iron. Lunar and Planetary Science, XXX, Abstract \#1334, Lunar and Planetary Institute, Houston (CD-ROM).

Skála, R., Frýda, J. and Sekanina, J. (2000) Mineralogy of the Vicenice octahedrite. Journal of the Czech Geological Society, 45, 175-192.

[Manuscript received 2 October 2002:

revised 2 June 2003] 